\title{
AUTOKOLERASI SPASIAL KEMISKINAN DAN LUAS LAHAN PERTANIAN DI KABUPATEN MESUJI
}

\author{
${ }^{1}$ Tasha Adiza
}

\begin{abstract}
This research aims to examine the spatial analysis autocorrelation to determine the pattern of relationships or correlations between locations (observations). In the case of the percentage of poverty in Mesuji Regency and the influence of agricultural land area, this method will provide important information in analyzing the relationship between the characteristics of poverty between regions. Therefore, in this study, a spatial autocorrelation analysis was carried out on the percentage of population poverty data in 2017. The methods used were the Morans I test and the Local Indicator of Spatial Autocorrelation (LISA). The results of the spatial autocorrelation of poverty among 7 sub-districts in Mesuji Regency in 2017 are spatially clustered. Poverty grouping occurs where there are sub-districts that have almost the same observational value as subdistricts that are located close to each other or neighbors.There is one grouping based on the level of poverty, which consists of one high-high cluster, namely Panca Jaya District. low-low cluster group. While the high-low outliers and low-high-outliers categories were not found in the inter-district research area in Mesuji Regency. Variable Agricultural land area has a negative and significant effect on the percentage of poor people in Mesuji Regency in 7 Districts in a statistical model, increasing agricultural land will decrease the percentage the poor.
\end{abstract}

Keywords: Spatial Autokolerasi, agricultural land area, poverty

\begin{abstract}
Abstrak
Penelitian ini bertujuan untuk meneliti Autokorelasi analisis spasial untuk mengetahui pola hubungan atau korelasi antar lokasi (amatan). Pada kasus persentase kemiskinan di Kabupaten Mesuji dan pengaruh luas lahan pertanian, metode ini akan memberikan informasi penting dalam menganalisis hubungan karakteristik kemiskinan antar wilayah. Oleh karena itu, dalam penelitian ini dilakukan analisis autokorelasi spasial pada data persentase kemiskinan penduduk pada tahun 2017. Metode yang digunakan adalah uji moran's I dan Local Indicator of Spatial Autocorrelation (LISA). Hasil penelnelitian Autokorelasi spasial kemiskinan antar 7 kecamatan di Kabupaten Mesuji tahun 2017 secara spasial pola sebarannya bersifat menggerombol (clustered). Pengelompokkan kemiskinan terjadi dimana terdapat kecamatan yang memiliki nilai amatan yang hampir sama dengan kecamatan yang letaknya saling berdekatan atau bertetangga Terdapat satu pengelompokan berdasarkan tingkat kemiskinan, dimana terdiri dari satu kelompok high-high cluster yaitu Kecamatan Panca Jaya. kelompok low-low cluster. Sedangkan kategori high-low outliers dan low-highoutliers tidak ditemukan di wilayah penelitian antar Kecamatan di Kabupaten Mesuji.Variabel Luas lahan pertanian berpengaruh negatif dan signifikan terhadap persentase penduduk miskin di Kabupaten Mesuji di 7 Kecamatan dalam model secara statistik, peningkatan Lahan Pertanian akan menurunkan perentase penduduk miskin.
\end{abstract}

Kata Kunci: Autokolerasi Spasial,Luas lahan pertanian, kemiskinan 


\section{PENDAHULUAN}

Masalah kemiskinan menjadi salah satu persoalan yang mendasar dan menjadi fokus perhatian pemerintah di negara manapun termasuk Indonesia. Bangsa Indonesia mempunyai perhatian besar terhadap terciptanya masyarakat yang adil dan makmur sebagaimana termuat dalam alinea keempat Undang-Undang Dasar 1945. Hingga pada saat ini ketika Bangsa Indonesia telah merdeka selama lebih dari 72 tahun kemiskinan masih sulit teratasi dan masih merupakan salah satu agenda utama pembangunan nasional.

Kabupaten Mesuji merupakan salah satu daerah otonomi di Provinsi Lampung yang baru akan berusia sebelas tahun pada bulan November 2019. Masih begitu banyak tugas-tugas pembangunan yang harus dilaksanakan oleh Pemerintah Daerah dan seluruh lapisan masyarakat Kabupaten Mesuji, salah satunya adalah penanggulangan kemiskinan. Berdasarkan Data BPS mengenai Persentase Penduduk Miskin di Provinsi Lampung dirinci menurut Kabupaten/Kota Tahun 2012-2016 jika dibandingkan dengan kabupaten/kota lainnya di Provinsi Lampung, tingkat kemiskinan di Kabupaten Mesuji selama kurun waktu 2012-2016 memang yang terendah. Persentase penduduk miskin di Kabupaten Mesuji selama kurun waktu tersebut juga selalu jauh berada diatas rata-rata kemiskinan di Provinsi Lampung.

Secara rinci persentase penduduk miskin di Provinsi Lampung dirinci menurut Kabupaten/Kota tahun 2012-2016 disajikan pada Tabel 1.

Tabel 1.Persentase Penduduk Miskin di Provinsi Lampung dirinci menurut Kabupaten/Kota tahun 2012-2016

\begin{tabular}{lccccc}
\hline \multicolumn{1}{c}{ Kabupaten/Kota } & $\mathbf{2 0 1 2}$ & $\mathbf{2 0 1 3}$ & $\mathbf{2 0 1 4}$ & $\mathbf{2 0 1 5}$ & $\mathbf{2 0 1 6}$ \\
\hline \hline 1. Lampung Barat & 15,13 & 13,96 & 13,70 & 14,18 & 15,06 \\
2. Tanggamus & 16,10 & 15,24 & 14,95 & 14,26 & 14,05 \\
3. Lampung Selatan & 18,19 & 17,09 & 16,77 & 16,27 & 16,16 \\
4. Lampung Timur & 18,59 & 17,38 & 17,05 & 16,91 & 16,98 \\
5. Lampung Tengah & 14,96 & 13,37 & 13,13 & 13,30 & 13,28 \\
6. Lampung Utara & 25,16 & 23,67 & 23,32 & 23,20 & 22,92 \\
7. Way Kanan & 16,54 & 15,36 & 15,03 & 14,61 & 14,58 \\
8. Tulang Bawang & 9,43 & 8,04 & 8,66 & 10,25 & 10,20 \\
9. Pesawaran & 18,01 & 17,86 & 17,51 & 17,61 & 17,31 \\
10.Pringsewu & 11,01 & 9,81 & 9,83 & 11,80 & 11,73 \\
11. Mesuji & 7,69 & 5,81 & 6,57 & 8,20 & 8,00 \\
12. Tulang Bawang Barat & 6,73 & 6,31 & 7,12 & 8,23 & 8,40 \\
13.Pesisir Barat & - & - & - & 15,81 & 15,91 \\
14. Bandar Lampung & 12,65 & 10,85 & 10,60 & 10,33 & 10,15 \\
15. Metro & 12,09 & 11,08 & 10,82 & 10,29 & 10,15 \\
\hline Provinsi Lampung & 15,65 & 14,39 & 14,21 & 14,35 & 14,29 \\
\hline
\end{tabular}

Sumber: Badan Pusat Statistik ProvinsiLampung, Tahun 2018.

Meskipun jika dibandingkan dengan daerah Kabupaten/Kota lainnya di Provinsi Lampung kemiskinan di Kabupaten Mesuji merupakan yang terendah, namun jika 
dilihat kinerja pengentasan kemiskinan di Kabupaten Mesuji dalam kurun waktu tersebut tidaklah selalu berhasil. Persentase penduduk miskin di Kabupaten Mesuji pernah mengalami peningkatan secara kontinyu selama tahun 2013-2015.

Berbagai program dan kegiatan dalam rangka penganggulangan kemiskinan di Kabupaten Mesuji telah dilakukan baik melalui program Pemerintah Pusat, Pemerintah Daerah Provinsi, dan Pemerintah Kabupaten Mesuji pada setiap tahunnya. Pada saat ini, kebijakan penanggulangan kemiskinan di Kabupaten Mesuji dituangkan dalam Rencana Aksi Daerah (RAD) Penanggulangan Kemiskinan Kabupaten Mesuji yang disusun oleh Pemerintah Kabupaten Mesuji pada tahun 2014 yang lalu. Strategi dan kebijakan dalam RAD tersebut hanya menggunakan pendekatan sektoral, belum mempertimbangkan ketergantungan spasial dan keragaman spasial. Padahal integrasi aspek spasial dalam penanggulangan kemiskinan sangatlah penting mengingat lokasi geografis sangat mempengaruhi dinamika kemiskinan.

Upaya penanggulangan kemiskinan tidak cukup hanya dengan kebijakan-kebijakan yang bersifat umum dan melalui pendekatan sektoral seperti yang selama ini dilaksanakan. Pendekatan spasial dan lokalitas diperlukan untuk mengetahui sampai ke akar permasalahan sehingga solusi dan program kerja penanggulangan kemiskinan dapat disesuaikan dengan karakteristik daerah tersebut.masalah kemiskinan dipengaruhi oleh lokasi (spasial). Adanya pengaruh lokasi pada masalah kemiskinan mengakibatkan wilayah dengan tingkat kemiskinan tinggi akan memberikan pengaruh terhadap wilayah sekitarnya. Kondisi inimemungkinkan terbentuknya kelompok-kelompok atau gerombol wilayah dengan tingkat kemiskinan yang sama atau mirip.

Oleh karena itu, selain pendekatan sektoral, penanggulangan kemiskinan di Kabupaten Mesuji harus dilakukan melalui pendekatan spasial dan lokalitas agar kemiskinan dapat teridentifikasi sampai ke akar permasalahan sehingga solusi dan program kerja penanggulangan kemiskinan dapat disesuaikan dengan karakteristik daerah tersebut. Permasalahan yang diangkat dalam penelitian ini adalah sebagai berikut:

1. Apakah terjadi keterkaitan spasial penduduk miskin di 7 Kecamatan di Kabupaten Mesuji ?

2. Melihat Evaluasi Model yang terbaik antara model tanpa konsep spasial atau dengan konsep spasial untuk meganalisis kemiskinan di 7 Kecamatan di Kabupaten Mesuji.

3. Bagaimanakah pengaruh variabel penggunaan lahan terhadap kemiskinan di 7 Kecamatan di Kabupaten Mesuji ?

\section{METODOLOGI PENELITIAN}

\section{Lokasi Penelitian}

Lokasi penelitian ini meliputi seluruh wilayah administrasi di Kabupaten Mesuji, yaitu terdiri dari 7 kecamatan, yaitu Kecamatan Way Serdang, Kecamatan Simpang Pematang, Kecamatan Panca Jaya, Kecamatan Tanjung Raya, Kecamatan Mesuji, Kecamatan Mesuji Timur dan Kecamatan Rawajitu Utara. 
Tabel 2. Definisi dan Operasional Variabel Penelitian

\begin{tabular}{llll}
\hline \multicolumn{1}{c}{ Simbol } & \multicolumn{1}{c}{ Variabel } & \multicolumn{1}{c}{ Definisi Operasional } & \multicolumn{1}{c}{ Sumber Data } \\
\hline \hline PKMS & Kemiskinan & Persentase penduduk miskin & Pemerintah Daerah \\
& kecamatan & $\begin{array}{l}\text { pada 7 kecamatan di } \\
\text { Kabupaten Mesuji. }\end{array}$ & $\begin{array}{l}\text { Kabupaten Mesuji, } \\
\text { BPS, Profil } \\
\text { Kecamatan }\end{array}$ \\
\hline LHN & Luas lahan & Rasio luas lahan pertanian & Pemerintah Daerah \\
& pertanian (sawah, & pada setiap seluruh guna & Kabupaten Mesuji, \\
& kebun, ladang) & lahan kebutuhan penduduk di & BPS, Profil \\
& & 7 kecamatan kabupaten \\
& Mesuji. & Kecamatan \\
& & & \\
\hline
\end{tabular}

\section{Metode Analisis Data}

\section{Analisis Pola Spasial Kemiskinan di Kabupaten Mesuji}

Analisis pola spasial kemiskinan dalam penelitian ini menggunakan tiga teknik analisis seperti yang telah dilakukan oleh Irawadi (2018), yaitu Indeks Moran Global dan Moran Lokal Anselin

\section{Analisis Indeks Moran Global}

Pengukuran autokorelasi Spasial menggunakan Indeks Moran global :

Dimana merupakan rata-rata observasi dan penimbang keterkaitan antara wilayah i dan $\mathrm{j}$.

Dalam melakukan pengujian terhadap output Indeks Moran I yang dihasilkan, dapat digunakan hipotesis sebagai berikut :

$$
\begin{aligned}
& \mathrm{H}_{0}=\text { Tidak ada Autokorelasi Spasial } \\
& \mathrm{H}_{\mathrm{a}}=\text { Terdapat Autokorelasi Spasial }
\end{aligned}
$$

Keterangan : pada penelitian ini $\mathrm{H}_{0}$ ditolak pada saat $-\mathrm{Z}(I)<-1,645$

Jika nilai $\mathrm{Z}(I)>$ dari $\mathrm{Z}_{\alpha / 2}$ atau $-\mathrm{Z}(I)<-\mathrm{Z}_{\alpha / 2}$ maka dapat disimpulakan bahwa terdapat keterkaitan wilayah yang signifikan pada tingkat signifikansi $\alpha$. Rentang nilai dari Indeks Moran dalam kasus matriks pembobot spasial terstandarisasi adalah $-1 \leq \mathrm{I} \leq$ 1.Nilai $-1 \leq \mathrm{I}<0$ menunjukkan adanya autokorelasi spasial negatif, sedangkan nilai $0<$ $\mathrm{I} \leq 1$ menunjukkan adanya autokorelasi spasial positif, nilai Indeks Moran bernilai nol mengindikasikan tidak berkelompok.

Autokorelasi spasial adalah korelasi antara variabel dengan dirinya sendiri berdasarkan ruang atau bisa dikatakan kemiripan objek dalam suatu ruang, baik jarak, waktu ataupun wilayah.Besaran autokorelasi spasial dapat digunakan untuk mengidentifikasi hubungan spasial (Anselin, 1988). Seringkali antar kecamatan yang berdekatan mempunyai karakteristik atau indikator yang mirip. Jadi terjadi korelasi dalam ruang atau tempat, bukan korelasi antara data suatu waktu ke waktu lainnya.Untuk pengukuran autokorelasi spasial dapat dihitung menggunakan Indeks Moran dengan rumus sebagai berikut: 


\section{Dimana:}

I $\quad=$ Indeks Moran

$\mathrm{n} \quad=$ Banyaknya lokasi amatan (kecamatan)

$\mathrm{Xi} \quad=$ Nilai pada lokasi kecamatan $\mathrm{i}$

$\mathrm{Xj} \quad=$ Nilai pada lokasi kecamatan $\mathrm{j}$

$=$ Nilai rata-rata dari (xi) dari n lokasi.

$w i j=$ Elemen pada pembobot ter standarisasi antara kecamatan $\mathrm{i}$ dan $\mathrm{j}$.

Hipotesis untuk uji menggunakan indeks Moran tersebut adalah:

Ho : Tidak adanya auto korelasi spasial antar kecamatan di Kabupaten Mesuji.

$\mathrm{Ha}$ : Adanya auto korelasi spasial antar kecamatan di Kabupaten Mesuji.

Nilai I sama dengan koefisien korelasi yaitu diantara -1 sampai 1. Nilai yang tinggi mengartikan bahwa korelasinya tinggi, sedangkan nilai 0 mengartikan tidak adanya autokorelasi. Akan tetapi untuk mengatakan ada atau tidak adanya autokorelasi perlu dibandingkan nilai statistik I dengan nilai harapannya. Nilai harapan dari I adalah:

Indeks Moran banyak digunakan untuk mengukur autokorelasi spasial global dan untuk pengujian autokorelasi spasial secara lokal dapat digunakan Indeks LISA yang mengidentifikasi bagaimana hubungan antara suatu lokasi pengamatan terhadap lokasi pengamatan lain(Lee dan Wong, 2001). statistik uji yang digunakan diturunkan dari sebaran normal baku, yaitu :

Keterangan:

I $\quad=$ Indeks moran

$\mathrm{Z}(\mathrm{I})$ = Nilai statistik uji indeks Moran

$\mathrm{E}(\mathrm{I})=$ Nilai harapan dari indeks Moran

Dimana:

$$
\begin{aligned}
& \operatorname{Var}(I)=\frac{N^{2} S_{1}-N S_{2}+3 S_{0}^{2}}{S_{0}^{2}\left(N^{2}-1\right)} \\
& S_{0}=\sum_{I}^{N} \sum_{j}^{N} W_{i j} \\
& S_{1}=\frac{1}{2} \sum_{I}^{N} \sum_{J}^{N}\left(W_{i j}+W_{j i}\right)^{2} \\
& S_{2}=\sum_{k}^{N}\left(\sum_{j}^{N} W_{k j}+\sum_{i}^{N} W_{i k}\right)^{2}
\end{aligned}
$$

Jika $\mathrm{Z}(\mathrm{I})>\mathrm{Z}_{1-\alpha}$ maka $\mathrm{H} 0$ ditolak (terdapat autokorelasi spasial positif). Rentang skala numerik Indeks Moran yang digunakan untuk melihat adanya autokorelasi spasial seperti yang terlihat pada tabel (Lee dan Wong, 2001:80)

\section{Tabel 3. Skala Indeks Moran}


1 Terdapat pola klaster/berkelompok dengan titik-titikyang $\mathrm{I}>\mathrm{E}(\mathrm{I})$ berdekatan menunjukkan karakteristik yang sama (autokorelasi spasial positif)

2 Pola acak atau tidak ada pola tertentu yang di tunjukkan oleh titik-titik berdasarkan karakteristik

3 Autokorelasi spasial negatif, dengan titik-titikyang berdekatan $\mathrm{I}<\mathrm{E}(\mathrm{I})$ menunjukkan karakteristik yangberbeda

Sumber: Lee dan Wong, 2001.

Uji autokorelasi dalam penelitian ini menggunakan alat analisis Spatial Autocorrelation (Indeks Moran) dari software Geoda. Tool akan menghitung autokorelasi spasial berdasarkan nilai atribut dan lokasi dari masing-masing kecamatan. Dari nilai atribut dan lokasi tersebut, tool akan menyajikan output nilai Indeks Moran dan pola yang terbentuk apakah bersifat berkelompok/bergerombol (clustered), acak (random), atau menyebar (dispersed). Dari hasil output ini dapat disimpulkan apakah terjadi autokorelasi pada tingkat kemiskinan kecamatan di Kabupaten Mesuji.

\section{Analisis Moran Lokal Anselin}

Penjelasan rumus dan tabel pada poin sebelumnya adalah untuk menghitungIndeks Moran Global. Diperlukan satu alat lagi untuk mendeteksi local indicators of spatial association (LISA). Alat yang digunakan adalah Indeks Moran Lokal.Syarat analisis LISA ada dua, yaitu:

1) LISA untuk masing-masing observasi mengindikasikan adanya pengelompokan spasial yang signifikan di sekitar wilayah pengamatan;

2) Penjumlahan LISA untuk semua observasi adalah proporsional dengan indikator keterkaitan spasial global (Anselin, 1995).

Tujuan dari LISA adalah mengidentifikasi pengelompokan dan outlier spasial. Rumusan dari Indeks Moran Lokal sebagai berikut :

$$
I_{i}=\frac{\left(X_{i}-\bar{X}\right) \sum_{j=1}^{N} w_{i j}\left(X_{j}-\bar{X}\right)}{\sum_{i=1}^{N}\left(X_{i}-\bar{X}\right)^{2} / n}
$$

Di mana :

Ii $\quad=$ Indeks Moran wilayah i

$\mathrm{Wij}=$ Elemen penimbang spasial yang mengacu pada letak wilayah i terhadap wilayah tetangga $\mathrm{j}$

$\mathrm{X}=$ rata-rata

$\mathrm{Xi} \quad=$ Nilai variabel pengamatan wilayah $\mathrm{i}$

$\mathrm{Xj} \quad=$ Nilai variabel pengamatan wilayah $\mathrm{j}$

Jika nilai Ii positif dan signifikan maka pengelompokan wilayah yang terjadi di sekitar wilayah i merupakan pengelompokan wilayah yang memiliki karakteristik sama dengan wilayah j. Sebaliknya, nilai Ii negatif dan signifikan maka pengelompokan wilayah yang terjadi di sekitar wilayah i merupakan pengelompokan wilayah yang memiliki karakteristik berbeda dengan wilayah $\mathrm{j}$. 


\section{Sistem Informasi Geografis}

Dalam penilitian ini SIG yang digunakan adalah aplikasi softwareGeoda dimana aplikasi ini mengumpulkan, mempersiapkan, dan menyimpan data spasial dari perhitungan spasial yang dilakukan dengan memasukan hasil perhitungan spasial. input data dan manajemen data spasial dan komposisi atau tata letak peta spasial di gambarkan dengan GeodaMap sesuai dengan input data besaran dari nilai spasial atau data yang didapat.

\section{Analisis Penggunaan Lahan}

Penggunaan lahan di Kabupaten Mesuji diperoleh dengan melakukan analisis spasial menggunakan software Geoda. Peta penggunaan tanah ditumpang susun (overlay) dengan peta batas kecamatan untuk mendapatkan luas penggunaan lahan sesuai klasifikasi yang ditentukan. Klasifikasi penggunaan lahan yang digunakan adalah hutan, sawah, kebun/perkebunan, pemukiman, lahan tegalan/ladang, lahan tambak/kolam, dan lahan non produktif (alang-alang, padang rumput, tanah kosong, dan lainnya).

Hasil analisis tumpang susun didapatkan informasi penggunaan lahan di setiap kecamatan yang merupakan unit pengamatan. Penggunaan lahan yang digunakan sebagai variabel-variabel dalam penelitian ini adalah penggunaan lahan yang berkaitan dengan pertanian dalam arti luas, yaitu luas lahan sawah, luas lahan perkebunan, luas lahan tegalan/ladang di setiap kecamatan.

\section{Analisis Model Pengaruh dengan Menggunakan Konsep Spasial}

\section{Model Umum Regresi Spasial (SARMA)}

Anselin (1998) mengembangkan model regresi spasial dengan menggunakan data spasial crosssection. Model umum regresi spasial atau juga bisa disebut Spatial Autoregressive Moving Average(SARMA) dapat disajikan sebagaimana persamaan (2) dan (3)

$y=\rho W y+X \beta+u$

$u=\lambda W u+\varepsilon$

$\varepsilon \sim N\left(0, o^{2} I\right)$

Dimana :

$y:$ vektor variabel dependent

$\rho$ : parameter koefisien otokorelasi spasial pada variabel dependent

$\mathrm{W}$ : matriks pembobot

$X$ : matriks variabel independent

$\beta$ : vektor koefisien parameter regresi

$\lambda$ : parameter koefisien otokorelasi spasial galat

$\varepsilon$ : vektor error

\section{Model Otoregresif Spasial (SAR)}

Anselin (1998) mengambarkan Model Otoregresif Spasial (SAR) dalam persamaan (3) Jika $\rho \neq 0$ dan $\lambda \neq 0$, maka persamaan menjadi :

$y=\rho W y+\beta X+\varepsilon$

$\varepsilon \sim \mathrm{N}\left(0, \mathrm{o}^{2} \mathrm{I}\right)$

Dimana:

$y$ : vektor variabel dependent 
$\rho:$ parameter koefisien otokorelasi spasial pada variabel dependent

$\mathrm{W}$ : matriks pembobot

$\beta$ : vektor koefisien parameter regresi

$X$ : matriks variabel independent

$\varepsilon$ : vektor error

Hipotesis yang digunakan dalam uji signifikan regresi spasial autoregressiveadalah sebagai berikut:

H0 $: \rho=0$ (Parameter tidak signifikan)

Ha $: \rho \neq 0$ (Parameter signifikan)

Pengambilan keputusan.dengan kriteria sebagai berikut:

a. H0 ditolak yang artinya Ha diterima, jika $\mathrm{Z}$ hitung $>\mathrm{Z}$ tabel atau $p$-value $<\alpha=5$ persen, bahwa koefisien regresi signifikan sehingga layak digunakan pada model.

b. H0 diterima yang artinya Ha ditolak, jika $\mathrm{Z}$ hitung $<\mathrm{Z}$ tabel atau $p$-value $>\alpha=5$ persen, bahwa koefisien regresi tidak signifikan sehingga tidak layak digunakan pada model.

\section{Model Galat Spasial (SEM)}

Anselin (1998) mengambarkan Model Galat Spasial (SEM) dalam persamaan (4)

Jika $\rho=0$ dan $\lambda \neq 0$, maka persamaan menjadi :

$y=X \beta+u$

$u: \lambda W u+\varepsilon$, Dengan $\varepsilon \sim N\left(0, o^{2} I\right)$

Dimana :

$y:$ vektor variabel dependent

$X$ : matriks variabel independent

$\beta$ : vektor koefisien parameter regresi

$\lambda$ : parameter koefisien otokorelasi spasial galat

$\varepsilon$ : vektor error

$W$ : matriks pembobot

Hipotesis yang digunakan dalam uji signifikan regresi spasial error adalah sebagai berikut:

$\mathrm{H} 0: \lambda=0$ (Parameter tidak signifikan)

Ha $: \lambda \neq 0$ (Parameter signifikan)

Pengambilan keputusan dengan kriteria sebagai berikut:

a. H0 ditolak yang artinya Ha diterima, jika $\mathrm{Z}$ hitung $>\mathrm{Z}$ tabel atau $p$-value $<\alpha=5$ persen, bahwa koefisien regresi signifikan sehingga layak digunakan pada model

b. H0 diterima yang artinya Ha ditolak, jika $\mathrm{Z}$ hitung $<\mathrm{Z}$ tabel atau $p$-value $>\alpha=5$ persen, bahwa koefisien regresi tidak signifikan sehingga tidak layak digunakan pada model.

\section{HASIL DAN PEMBAHASAN}

Berdasarkan lokasi dan persentase yang hampir sama tersebut dapat dikatakan bahwa angka kemiskinan membentuk suatu pola penyebaran yang mengelompok pada beberapa lokasi. Untuk membuktikan hal ini perlu di uji melalui autokorelasi spasial 
Moran's I dan LISA.Detail Pola persentase penduduk miskin di 7 Kecamatan di Kabupaten Mesuji disajikan pada Gambar 1 .
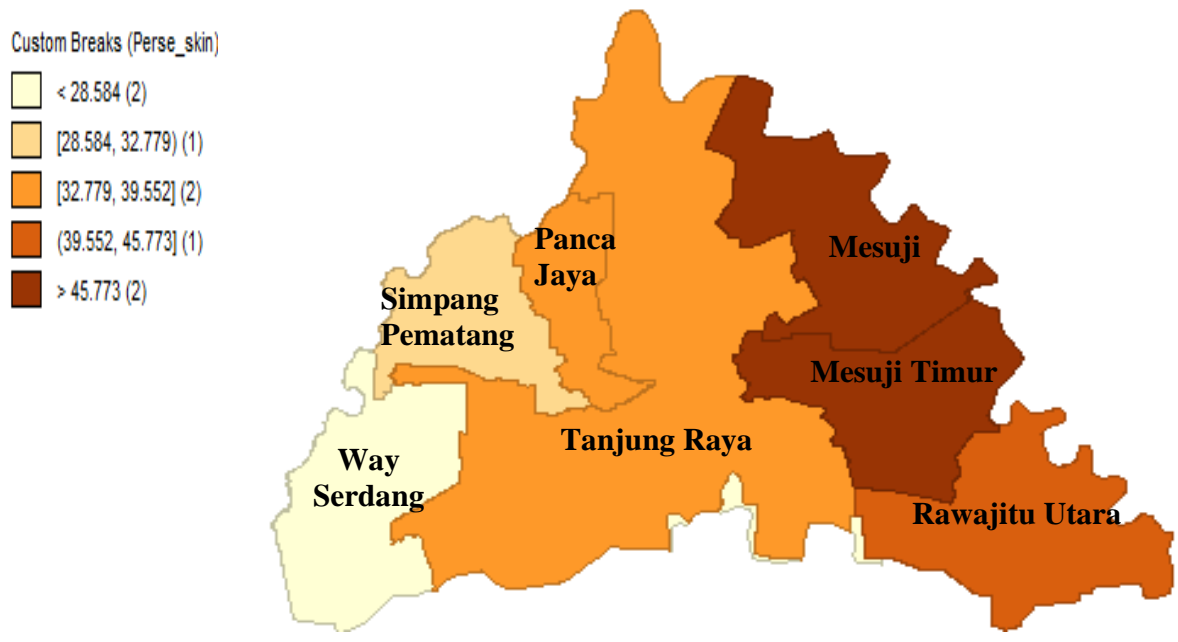

Gambar 1. Pola Persebaran Penduduk Miskin 7 Kecamatan di Kab.Mesuji Tahun 2017, Data diolah Geoda 2020

\section{Analisis Indeks Moran Global}

Analisis Indeks Moran Global digunakan untuk menganalisis adanya autokorelasi spasial kemiskinan di Kabupaten Mesuji. Berdasarkan hasil outputtoolSpatial Autocorrelation (Indeks Moran) dari software Geoda terlihat bahwa pola spasial sebaran kemiskinan bersifat menggerombol(clustered).

Tabel 4. Hasil perhitungan Indeks Moran

\begin{tabular}{cccc}
\hline Tahun & Moran's $\boldsymbol{I}$ & $\boldsymbol{E}(\boldsymbol{I})$ & $\boldsymbol{z}$-value \\
\hline 2017 & 0,015873 & $-0,1429$ & 1,9443 \\
\hline
\end{tabular}

Sumber: Data diolah Open Geoda,2020.

Keterangan $: I_{i}$ positif dan signifikan = autokorelasi positif dengan pola mengelompok yang memiliki karakteristik yang sama.

Berdasarkan data pada Tabel 4, nilai perhitungan indeks moran's pada tahun 2017 menunjukkan nilai $\mathrm{I}_{\mathrm{i}}$ yang positif. Hal ini mengindikasikan adanya tingkat keterkaitan spasial berupa autokorelasi positif yang berarti terdapat pola pengelompokkan (clustered) wilayah dengan karakteristik yang sama. Untuk melihat apakah terjadi keterkaitan spasial signifikan secara statistik maka dilakukan uji Z. Jika nilai Z lebih besar dari $Z_{\alpha / 2}$ atau lebih kecil dari $-Z_{\alpha / 2}$ maka dapat disimpulkan bahwa terdapat keterkaitan wilayah yang signifikan pada tingkat signifikansi $\alpha$. Pada penelitian ini, nilai kritis $\alpha$ sebesar $5 \%$ atau $Z_{0,95}=1,654$. 


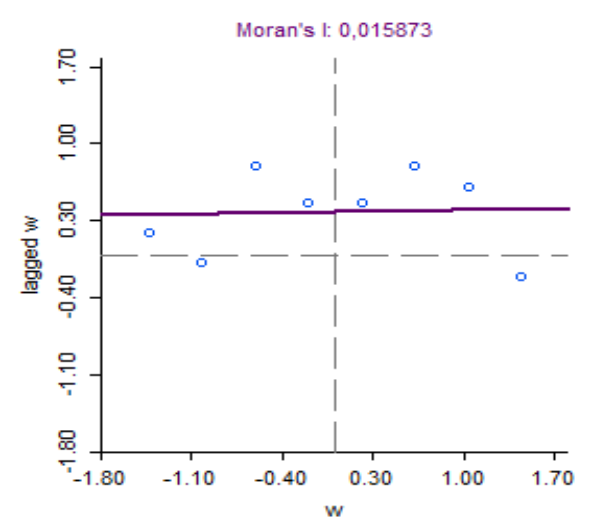

\section{Gambar 2. Moran Scatterplot persentase Penduduk Miskin Tahun 2017 Sumber: Geoda diolah,2020.}

Nilai Indeks Moran yang dihasilkan bernilai positif yaitu 0,015873 sehingga dapat disimpulkan bahwa terdapat autokorelasi spasial kemiskinan antar kecamatan dan secara spasial pola sebarannya bersifat menggerombol (clustered). Pengelompokkan kemiskinan terjadi dimana terdapat kecamatan yang memiliki nilai amatan yang hampir sama dengan kecamatan yang letaknya saling berdekatan atau bertetangga.

Hasil yang diperoleh dari Tabel 4, menunjukkan bahwa pada tahun 2017 terjadi keterkaitan spasial tingkat kemiskinan yang signifikan secara statistik dibuktikan dengan nilai $\mathrm{Z}(\mathrm{I})>\mathrm{Z}_{0.95}$ yaitu $1,9443>1,654$ yang berarti terjadi keterkaitan spasial tingkat kemiskinan yang signifikan secara statistik. Berikut ini merupakan hasil Cluster Map LISA pada Gambar 5.
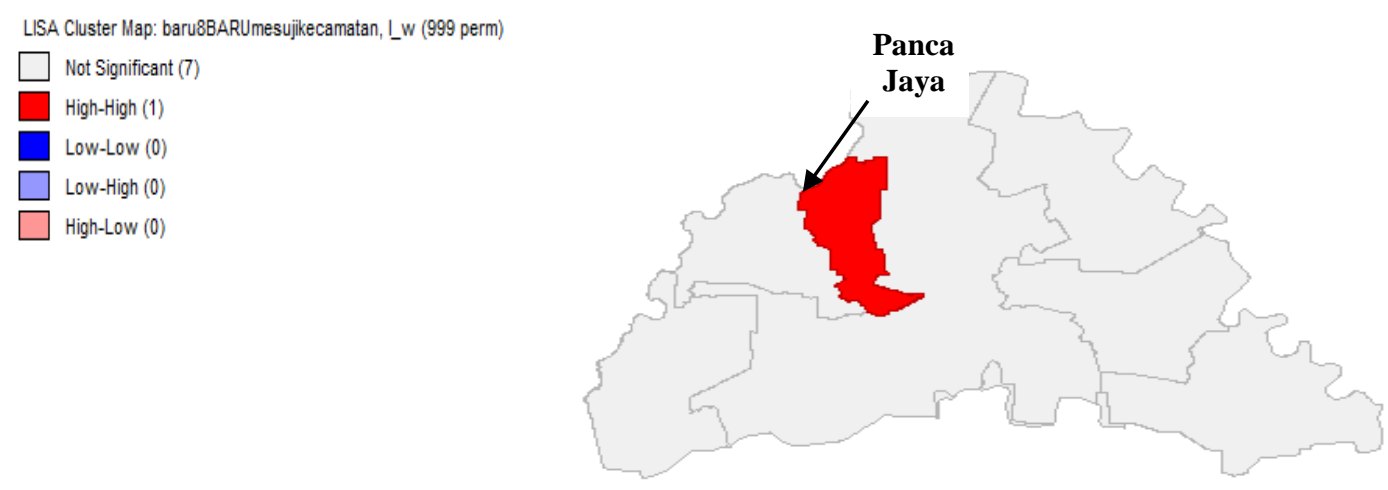

\section{Gambar 3. Peta LISA Signifikasi Kemiskinan Berbasis Kecamatan Sumber : Geoda Diolah,2020.}

Kabupaten Mesuji memiliki 7 Kecamatan yang saling bertetanggaam satu sama lain, konsep spasial autokorelasi Kaitan kontribusi wilayah tetangga untuk melihat trickledown effect keterkaitan persentase kemiskinan penduduk antar wilayah yang memiliki persentase penduduk miskin yang berbeda-beda. Perbedaaan keadaan sosial ekonomi yang ada tentu menjadi pembeda antar wilayah yang saling bertetanggaan keterkaitan antar ketetanggaan wilayah yang satu dengan lain bisa mendapatkan suatu spillover effect bagi wilayah yang saling berdekatan. Hasil LISA Tingkat kemiskinan Panca Jaya berdasarkan hasil LISA terjadi karena ada kontribusi dari wilayah 
tetangganya, Simpang Pematang, Tanjung Raya dan Mesuji.

\section{Pengaruh Penggunaan Lahan Pertanian dan Tingkat Perkembangan Kecamatan terhadap Kemiskinan di Kabupaten Mesuji dengan Konsep Spasial}

\section{Uji Efek Spasial}

Pengujian efek spasial dilakukan dengan menggunakan uji heterogenitas spasial yaitudengan uji Breusch Pagan. Nilai statistik Breusch pagan sebesar 1,3516 <khikuadrat sebesar 6,2514dan $p$-value $=0,50875>\alpha=0,10$, maka H0 diterima yang berarti tidak ada keragaman antar wilayah. Hasil kedua uji di atas mengindikasikan tidak ada efek spasial.

\section{Lagrange Multiplier (LM)}

Pemilihan model spasial dilakukan dengan Lagrange Multiplier (LM) sebagai identifikasi awal. Lagrange Multiplier (LM) digunakan untuk mendeteksi adanya efek spasial dengan lebih spesifik yaitu dengan menggunakan lag, error atau keduanya (lag dan error). Apabila LM lag dan LM error tidak signifikan maka dapat disimpulkan tidak terjadi keterkaitan spasial baik pada lag maupun error. Uji keterkaitan spasial dilakukan pada pembobot queen contiguity. Hasil pengujian Lagrange Multiplier (LM) pada Tabel 16 berikut :

Tabel 5. Hasil Lagrange Multiplier (LM)

\begin{tabular}{lllll}
\hline LM & Nilai & Khi-Square & P-value & Keterangan \\
\hline SARMA & 1,8239 & 4,60517 & 0,40174 & $\mathrm{H}_{0}$ diterima \\
SAR & 1,9200 & 2,70554 & 0,16585 & $\mathrm{H}_{0}$ diterima \\
SEM & 0,6856 & 2,70554 & 0,04076 & $\mathrm{H}_{0}$ ditolak \\
\hline
\end{tabular}

Sumber : data Geoda diolah 2020.

Berdasarkan Tabel 5 dapat dilihat dari masing-masing uji Lagrange Multiplier, hasilnya sebagai berikut :

$\checkmark$ Untuk SARMA, menerima $\mathrm{H}_{0}$ karena $p$-value $(0,40174)>\alpha=0,10$, sehingga terdapat ketergantungan spasial pada model tersebut, sehingga diperlukan pembentukkan model spatial lag dan error tersebut.

$\checkmark$ Untuk SAR, menerima $\mathrm{H}_{0}$ karena $p$-value $(0,16585)>\alpha=0,10$, sehingga tidak terdapat ketergantungan spasial pada model tersebut, sehingga tidak diperlukan pembentukkan model spatial lag tersebut.

$\checkmark$ Untuk SEM, menerima $\mathrm{H}_{0}$ karena $p$-value $(0,04076)<\alpha=0,10$, sehingga terdapat ketergantungan spasial pada model tersebut, sehingga diperlukan pembentukkan model spatial error tersebut.

\section{Pemilihan Model terbaik dari Regresi dengan Konsep Spasial}

Tabel 6. Perbandingan Model Regresi Klasik dan Model Regresi Spasial

\begin{tabular}{lccc}
\multicolumn{1}{c}{ Koefisien } & SARMA & SEM & SAR \\
\hline $\mathrm{R}^{2}$ & 0,905830 & 0,892598 & 0,870503 \\
AIC & 57,4315 & 56,666 & 57,3515 \\
Log Likelihood & $-24,7157$ & $-25,332983$ & $-25,6758$ \\
\hline
\end{tabular}

Sumber : Data diolah Geoda,2020. 
Berdasarkan Tabel 6. Menunjukan nilai AIC pada SEM sebesar 56,666 dengan nilai Log Likelihood -25,332983 dan $\mathrm{R}^{2}$ 0,892598. nilai ini menunjukan bahwa Model Spasial SEM lebih baik dari pada model spasial lainnya. Kriteria yang digunakan untuk memilih model adalah nilai AIC beserta log likehood dan $\mathrm{R}^{2}$ Model dikatakan baik jika memiliki nilai AIC yang kecil dan memperoleh nilai log likehood yang lebih besar, serta mempunyai nilai $\mathrm{R}^{2}$ yang lebih besar. Model SEM dipilih untuk menganalisis kasus keterkaitan spasial persentase penduduk miskin di 7 Kecamatan di Kabupaten Mesuji.

\section{Perhitungan Regresi Spasial}

Hasil perhitungan Regresi Spatial Error Model (SEM)variabel dependen Persentase kemiskinan dengan variabel Independen Luas Lahan Pertanian untuk mengetahui pegaruh antara variabel independen dan dependen maka hasil perhitungan tersebut di implementasikan sebagai berikut:

Tabel 7. Persamaan Regresi Spatial Error Model (SEM)

\begin{tabular}{lcccc}
\multicolumn{1}{c}{ Variable } & Coefficient & Std.Error & Z-Value & P-value \\
\hline CONSTANT & 6,02093 & 0,040360 & 0,96781 & 0,96781 \\
LHN & $-0,000557$ & $-0,0001469$ & $-3,79710$ & 0,00015 \\
$\Lambda$ & $-0,52461$ & 0,280462 & $-1,87053$ & 0,00614 \\
\hline
\end{tabular}

Sumber : Geoda Regresi spasial data diolah,2020.

$\mathrm{R}^{2}: 0,892598$

Log likelihood: $-25,332983$

Akaike Info Criterion: 56,666

Model persamaan SEM secara umum, sebagai berikut :

$P K M S=6,02093-0,000557 \mathrm{LHN}_{i}+\mathrm{u}_{\mathrm{i}}$

$\mathrm{u}_{\mathrm{i}}=-0,524612+\varepsilon_{\mathrm{i}}$

Hasil Model regresi Spasial diatas juga menunjukkan $R$-square sebesar 0,892598 atau sebesar $89 \%$. R-square menginterpretasikan besaran persentase pengaruh semua variabel independen terhadap variabel dependen. Artinya dalam penelitian ini variabel bebas $89 \%$ berpengaruh terhadap persentase penduduk miskin, sedangakan $11 \%$ sisanya dipengaruhi oleh variabel lain yang tidak dimasukkan kedalam model penelitian. Selain itu diperoleh nilai koeifisien yangdapat merepresentasikan besaran pengaruh variabel independent tersebut terhadap variabel dependen.

Variabel luas lahan pertanian memiliki hubungan yang negatif dan signifikan terhadap variabel persentase penduduk miskin di Kabupaten Mesuji pada $\alpha=0,05$. Kesimpulan ini diperoleh dengan melihat $P$-value $<\alpha=0,05$.

\begin{tabular}{cl}
\hline Koefisien & \multicolumn{1}{c}{ Keterangan } \\
\hline$\beta_{0}$ & $\begin{array}{l}\text { Nilai 6,02093 dapat diartikan bahwa apabila variabel independen } \\
\text { Luas lahan pertanian dianggap konstan atau tidak mengalami } \\
\text { perubahan maka persentase penduduk miskin sebesar 0,776682 } \\
\text { persen. }\end{array}$ \\
\hline$\beta_{1}$ & Nilai $-0,000557$ dapat diartikan bahwa ketika Luas lahan \\
\hline
\end{tabular}


pertanian naik sebesar $1000 \mathrm{~m}^{2}$, maka persentase penduduk miskin mengalami penurunan sebesar 0,00057 persen dengan asumsi persentase penduduk miskin tetap.

Variabel Luas lahan pertanian menunjukkan pengaruh negatif dan signifikan secara statistik derajat kepercayaan 95 persen. Nilai koefisien -0,000557 dapat diartikan bahwa ketika Luas lahan pertanian naik sebesar $100 \mathrm{~m}^{2}$, maka persentase penduduk miskin mengalami penurunan sebesar 0,57 persen dengan asumsi persentase penduduk miskin tetap. Nilai koefisien yang positif menunjukkan adanya pengaruh negatif antara lahan pertanian dengan persentase penduduk miskin petani di Kabupaten Mesuji di 7 kecamatan .

Hal ini menunjukkan semakin luas lahan maka pendapatan semakin meningkat diduga karena ketika penduduk memiliki lahan pertanian akan meningkatkan suatu produktivitas. Tersedianya modal dasar yang sangat potensial untuk dijadikan basis ekonomi wilayah (masyarakat) yaitu (intensifikasi) lahan pertanian, perkebunan dan kehutanan yang dapat ditingkatkan produktivitasnya. hasil kegiatan usaha pertanian untuk kebutuhan hidup sehari-hari, apalagi mencukupi mendorong penerapan teknologi baru untuk peningkatan produktivitas.

Peran sektor pertanian dalam mengurangi kemiskinan dapat bersifat langsung dan tidak langsung. Secara langsung pembangunan pertanian akan meningkatkan produktivitas pertanian melalui peningkatan produktivitas total faktor (total factor productivity/TFP). Peningkatan produktivitas pertanian akan meningkatkan pendapatan petani dan lebih lanjut akan menurunkan kemiskinan, sedangkan peran secara tidak langsung adalah melalui sektor non pertanian. Pembangunan sektor pertanian pada awalnya akan memengaruhi pertumbuhan sektor pertanian dan pertumbuhan ekonomi secara agregat dan selanjutnya akan mengurangi kemiskinan.

\section{KESIMPULAN DAN SARAN}

\section{Kesimpulan}

1. Autokorelasi spasial kemiskinan antar kecamatan dan secara spasial pola sebarannya bersifat menggerombol (clustered).

2. Model SEM dipilih untuk menganalisis kasus keterkaitan spasial persentase penduduk miskin di 7 Kecamatan di Kabupaten Mesuji.

3. Variabel Luas lahan pertanian berpengaruh negatif dan signifikan terhadap persentase penduduk miskin di Kabupaten Mesuji di 7 Kecamatan dalam model secara statistik, peningkatan Lahan Pertanian akan menurunkan perentase penduduk miskin.

\section{Saran}

Pemerintah sebagai stakeholder harus fokus pada lahan yang dimiliki oleh masyarakat tentang intensifikasi dinilai menjadi upaya mutlak yang harus dilakukan untuk menjaga produksi pertanian. Intensifikasi pertanian salah satu usaha untuk meningkatkan hasil pertanian dengan cara mengoptimalkan lahan pertanian yang sudah ada. Tatakelola lahan, efisiensi lahan dan ruang harus terus di berikan solusi dan monitoring, Tersedianya modal dasar yang sangat potensial untuk dijadikan basis ekonomi wilayah 
masyarakat yaitu intensifikasi lahan pertanian Pemanfaatan lahan yang baik akan menyebabkan peningkatan taraf hidup masyarakat khususnya yang ada di Kabupaten Mesuji.

\section{DAFTAR PUSTAKA}

Anselin, L., \& Rey, S. J. (2010). Perspectives on Spasial Data Analisis. In Perspectives on Spasial Data Analysis (pp. 1-20). Springer Berlin Heidelberg.

Anselin L. 1988. Spatial Econometrics: Methods and Models. Netherlands Kluwer Academic Publ. ISBN-10: 9024737354

Anselin, Luc. 1995. Local Indicator of Spatial Association - LISA. Geographical Analysis, 27(2) : 93-115. http://onlinelibrary.wiley.com. Diunduh Tanggal 30 Juni 2020

Badan Pusat Statistik. 2018. Statistik Provinsi Lampung. Provinsi Lampung. Indonesia.

Badan Pusat Statistik. 2017. Data dan Informasi Kemiskinan Kabupaten/Kota Tahun 2016. Badan Pusat Statistik. https://www.bps.com

Bappeda, Badan Perencanaan dan Pembangunan Daerah. Kabupaten Mesuji, Tahun 2018.

Dinas Sosial Kabupaten Mesuji Perkembangan Penduduk Miskin Per Kecamatan di Kabupaten Mesuji ,Tahun 2017.

Irawadi, Ade. 2018.Analisis Kemiskinan Spasial dan Kaitannya dengan Sertifikasi Tanah dan Penggunaan Lahan Pertanian di Kabupaten Mamuju. Institut Pertranian Bogor. Bogor.

Lee J. and Wong S.W.D., Statistical Analysis with Arcview GIS, John Willey \& Sons, Inc., United Stated of America, 2001.

LeSage, J.P. (1999), The Theory and Practice of Spatial Econometrics, http://www.econ.utoledo.edu download pada tanggal 30 Juni 2020. 